No. 6(63), 2019, pp. 95-109

https://doi.org/10.12797/Politeja.16.2019.63.06

\author{
Małgorzata KUŁAKOWSKA (D) \\ Jagiellonian University in Kraków \\ malgorzata.kulakowska@uj.edu.pl
}

\title{
EP ELECTIONS AS A TOOL FOR MIGRANT POLITICAL PARTICIPATION
}

ABSTRACT The paper focuses on the European Parliament (EP) elections seen as a tool for migrant political participation. When migrating for work, EU migrants do not always consider naturalization as an optimal arrangement, being satisfied with rights connected with their EU citizenship. Therefore, in terms of voting strategies, they often limit their voting rights to those connected with the institutions of their country of birth. However, the particular political context might create additional motivation for participation in EP elections. I would argue that such a particular situation did occur in the United Kingdom in May 2019, when many EU migrants decided to exercise their right to vote in EP elections. Furthermore, many of them were then denied this right, which has been attributed by some to the lack of efficiency on part of British institutions. The paper will look at the institution of the European Parliament elections, analyzing both the normative justification of the formal arrangements and the empirical dimension of 2019 EP Elections in the United Kingdom in the context of the ongoing processes of Brexit.

Key words: Participation, EP elections, EU citizens, Brexit, the United Kingdom 


\section{INTRODUCTION}

The aim of the article is to analyse the participation of European Union (EU) citizens in the European Parliament (EP) elections of 2019 in the United Kingdom in the context of the ongoing processes of Brexit. The article is then divided into two main sections. The first is devoted to the institution of the European Parliament, as well as the normative and institutional framework of the EP elections. The second describes the British context of the EP elections and the experience of the EU citizens willing to participate in them. The focus is on the campaign launched by the3million organization, willing to represent EU citizens residing in the UK and their claims of disfranchisement. The article analyses the claims via the lens of the official and institutional responses.

As Janusz Ruszkowski points out, the European Parliament is one of the most democratic institutions within the political system of the European Union ${ }^{1}$ and the only one to debate publicly. ${ }^{2}$ As the body representing the EU citizens, it possesses strong intra-EU legitimacy. Finally, as the EU Parliament participates in the legislative process of the $\mathrm{EU}$, it comes to be associated with the concept of legislative power, although in fact it shares these powers with the Council of the European Union. ${ }^{3}$ Ruszkowski also notices the multilevel hybridity of EP activities, as its competences to control other EU institutions are supranational; political groups formed by MEPs are transnational, but voting electorates are national (they are related to and defined by the EU member states). ${ }^{4}$

\section{THE CONCEPT OF EU CITIZENSHIP}

Even though the calls for a broader set of political and social rights for European citizens ${ }^{5}$ were heard as early as the 1970s, it was not before 1992 and the Treaty on European Union that the legal concept of EU citizenship was introduced. Certainly, it reflected the broader shift towards a political union. Some thus call it political citizenship, ${ }^{6}$ which

J. Ruszkowski, Parlament Europejski. Dynamika instytucjonalna i kompetencyjna, Szczecin 2010, p. 5.

2 Ibid.

3 Ibid. Cf. J.J. Węc, "Pozycja Parlamentu Europejskiego w reżimie traktatu lizbońskiego", in A. Kirpsza, P. Musiałek, D. Stolicki (eds.), Podsumowanie siódmej kadencji Parlamentu Europejskiego (20092014), Kraków 2015, pp. 13-37; A. Wierzchowska, "Parlament Europejski: efektywny katalizator zmian ustrojowych czy niedecyzyjny współuczestnik? Ocena pozycji Parlamentu Europejskiego w systemie politycznym Unii Europejskiej z uwzględnieniem kadencji 2014-2019”, in A. Nitszke, J.J. Węc (eds.), Podsumowanie VIII kadencji Parlamentu Europejskiego. Wyzwania integracji europejskiej w latach 2014-2019, Kraków 2019, pp. 37-57.

4 J. Ruszkowski, Parlament Europejski..., pp. 5-6.

5 L. Tilindyte, EU citizenship rights. Briefing, European Parliamentary Research Service, III 2017, at <https://www.europarl.europa.eu/RegData/etudes/BRIE/2017/599361/EPRS_BRI(2017)599361 EN.pdf $>$, p. 2.

6 J. Ruszkowski, Parlament Europejski..., p. 101. 
cannot develop while ignoring cultural ties. EU citizenship is clearly additional to national citizenship and does not have a stand-alone character ${ }^{7}-$ it cannot be retained if one loses legal rights to citizenship in one's own country.

The number of political rights linked with EU citizenship were established, which could be categorized into three groups: rights relating to free movement and residence, political rights and right to diplomatic and consular protection. ${ }^{8} \mathrm{EU}$ citizens can move and reside freely within the European Union; they have the right to petition to the $\mathrm{Eu}-$ ropean Parliament, to propose a Citizens' Initiative, and are to be protected against discrimination'. Furthermore, citizens of EU member states are allowed to take part in EU and local elections in a country of residence, which is the focus of this paper. ${ }^{10}$

\section{THE POLITICS OF EU ELECTIONS}

EU elections are held according to national legal frameworks. Since 1979 these have been direct elections. ${ }^{11}$ Campaigns are led by national parties and are often dominated by national issues. Ruszkowski suggests that the chances of reelection depend more on the popularity inside one's own national political party than on the quality of work as a Member of the European Parliament (MEP) ${ }^{12}$ as the decisions regarding the candidates are made by the leaders of national parties and not by the EP political groups.

The level of participation in EU elections is visibly lower than in national parliamentary or presidential elections. There is also a great diversity across various EU members. ${ }^{13}$ In the United Kingdom the turnout in EU elections has been considerably lower than in other EU countries, reflecting Eurosceptical feelings of the British population ${ }^{14}$. Krzysztof Zuba suggests that the concept of the EU Parliament was one of the reasons behind British Euroscepticism, as it raised fears connected with parliamentary sovereignty.

EU elections are organized in all the member states within the same week. In the United Kingdom the electoral system in EU elections differs significantly from that operating in national elections. ${ }^{15}$ Zuba suggests even that establishing the proportion-

L. Tilindyte, "EU Citizenship Rights. Briefing", European Parliamentary Research Service, March 2017, p. 2, at <https://www.europarl.europa.eu/RegData/etudes/BRIE/2017/599361/EPRS_ BRI(2017)599361_EN.pdf>.

8 Ibid.

9 Cf. J. Ruszkowski, Parlament Europejski...

10 See ibid., pp. 100-102, 170-171.

11 Before 1979, MEPs were nominated by the members of national parliaments. See ibid., p. 97.

12 Ibid., p. 103.

13 L. Tilindyte, “EU Citizenship Rights...”, pp. 5-6.

14 Cf. K. Zuba, Dryfujace wyspy. Europejskie dylematy Brytyjczyków, Warszawa 2013, p. 284.

15 It was not always like that. The first electoral system established in 1978 included 78 single-member constituencies, following the first past the post rule on the territory of Great Britain and the single transferable vote method in a single three-mandate constituency in Northern Ireland. It was not until 1999 that the current system of proportional voting was accepted. Ibid., pp. 298-302. 
al voting system in the EP Elections in the UK in 1999 was more significant and had a greater impact than the introduction of the direct elections in 1979, as it created the opportunity for minor political parties to successfully compete for votes. ${ }^{16}$

Zuba mirrors Ruszkowski's opinion about the limited international dimension of the EU elections, especially in the British context. ${ }^{17}$ The results should then be analysed in the context of national rather than international politics. However, it might be speculated that the political significance of the EU elections has been increasing because of the tensions between the EU and the UK. ${ }^{18}$ Nicholas Aylott, analyzing the meaning of the EP elections in 2019, ironically contends that no other European election meant so much for Britain as [...] that the country was never supposed to hold. ${ }^{19}$

\section{EP ELECTIONS OF 2019 IN THE UNITED KINGDOM - IN THE CONTEXT OF BREXIT}

On 29 March 2017, Theresa May, serving as Prime Minister of the United Kingdom of Great Britain and Northern Ireland, notified the European Council of the intention to leave the European Union structures. ${ }^{20}$ The United Kingdom was thereby expected to leave the European Union by the end of March 2019, and not participate in the EP Elections in May 2019. ${ }^{21}$ However, the process of negotiating the Brexit terms and getting the deal accepted by the Commons proved extremely challenging, and the socalled May's withdrawal agreement was rejected by British MPs three times, making an extension, and UK participation in the EP elections, necessary. ${ }^{22}$

The European Parliamentary elections took place from 23 to 26 May 2019. In the United Kingdom voting was organized on Thursday, 23 May. With the turnout of $37.2 \%$ throughout the United Kingdom, the highest number of votes (32\%), and MEPs (28 out of 73 ) was gained by the recently established Eurosceptic political party,

16 Ibid., p. 308.

17 Ibid., pp. 302-303.

18 Especially if one analyses the pressure on the traditional British party system born out of gains of extreme Eurosceptic parties such as UKIP, the Brexit Party, or even the BNP. Cf. E. Carter, G. Loomes, T.C. Lundberg, "United Kingdom" in W. Gagatek (ed.), The 2009 Elections to the European Parliament: Country Reports, Florence 2010, p. 182.

19 N. Aylott, "Britain: Political Parties Polarising", in N. Bolin et al. (eds.), Euroflections. Leading Academics on the European Elections 2019, Sundsvall 2019, at <https://www.euroflections.se/globalassets/ovrigt/euroflections/euroflections_v3.pdf>, p. 74.

20 "Statement by the European Council (Art. 50) on the UK notification", European Council, 29 March 2017, at <http://www.consilium.europa.eu/en/press/press-releases/2017/03/29/euco-50-statementuk-notification/>; T. Kubin, "Wyjście Wielkiej Brytanii z Unii Europejskiej a zróżnicowanie integracji w UE”, Studia Europejskie, vol. 1 (2018), pp. 45-68.

21 K. Smets, "United Kingdom: European Elections in the Run-Up to Brexit", in L. De Sio, M.N. Franklin, L. Russo (eds.), The European Parliament Elections of 2019, Roma 2019, pp. 267-272.

22 P. Webb, “United Kingdom 2019 - the Election that Wasn't Supposed to Be”, in N. Bolin et al. (eds.), Euroflections..., p. 43; N. Aylott, "Britain..." 
the Brexit Party led by Nigel Farage, a former leader of the United Kingdom Independence Party (UKIP). Second place, with $20 \%$ of votes and 16 MEPs, was obtained by the pro-remain Liberal Democrats. The Labour Party came third, with $14.1 \%$ and 10 MEPs, and fourth place was obtained by the Greens, while the governing party, the Conservatives, were fifth, with only $9.1 \%$ of the votes. ${ }^{23}$

Chart 1. Results of the European Parliamentary Elections. BBC ${ }^{24}$

\section{How did the parties do in Great Britain?}

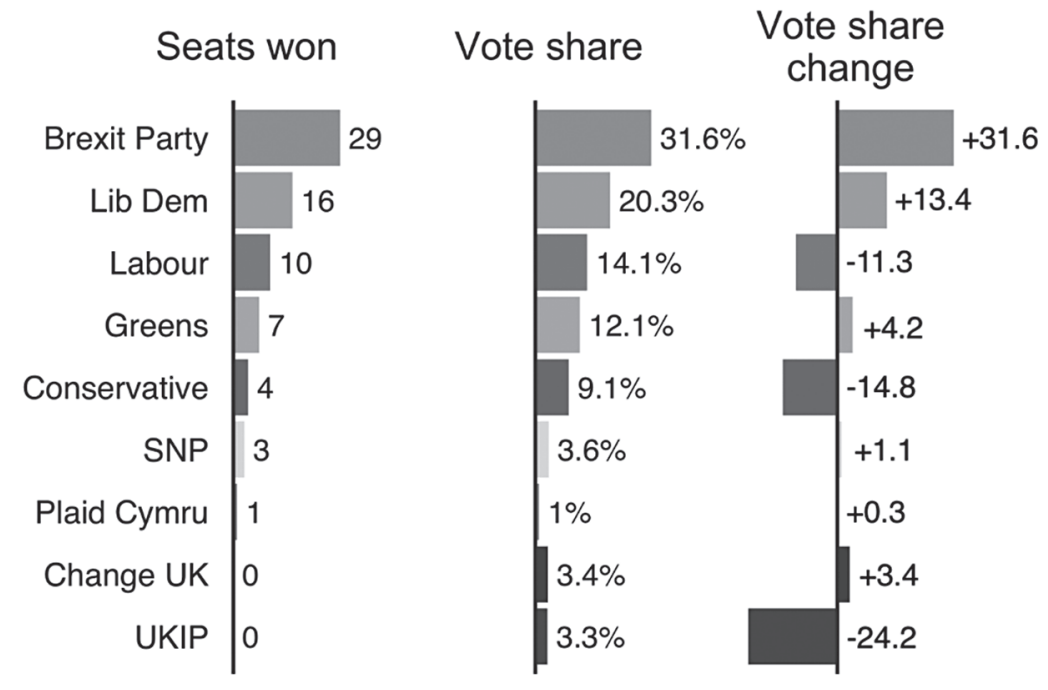

Source: Press Association

BBBC

While thorough analysis of the EP elections results goes well beyond the scope of this paper, it might be said that the mere fact they took place illustrated the inability of May's cabinet to deliver Brexit as promised..$^{25}$ In that context, it came as no surprise that Theresa May announced her resignation the day after the election. ${ }^{26}$ Paul Webb also points to lack of Labour clarity and internecine Tory paralysis creating the opportunity for smaller parties with clearer and more unified positions on Brexit ${ }^{27}$ to benefit, while Aylott ${ }^{28}$ emphasizes the polarizing effect the elections had on political parties.

\footnotetext{
23 K. Smets, "United Kingdom..."

24 "European Election 2019: The UK's Results in Maps and Charts", BBC News, 27 May 2019, at <https://www.bbc.com/news/uk-politics-48403131>.

25 See also D. Lilleker, "Voter Psychology in the Age of Anger: UK 2019", in N. Bolin et al. (eds.), Euroflections..., p. 46.

26 N. Aylott, “Britain...”; K. Smets, “United Kingdom...”

27 P. Webb, “United Kingdom 2019..., p. 43.

28 N. Aylott, "Britain...”
} 


\section{EU MIGRANTS IN THE UK}

Since EU citizens residing in the United Kingdom were not allowed to participate in the EU Referendum nor in the national elections held in 2017, the European Parliamentary elections might have been the last voting opportunity for them to express their growing feelings of frustration and alienation. ${ }^{29}$

In order for a citizen of the European Union to be eligible to vote, one needed to be a resident in the UK and at least 18 years of age. ${ }^{30}$ Everyone who wanted to take part in elections had to be registered. Additionally, as EU citizens could also take part in the EP elections via their own country's political system and voting twice is not allowed, there was an additional requirement of completing the EU citizen European Parliament voter registration form (commonly called a "UC1" form). ${ }^{31}$ The form needed to be signed in person and sent to the proper local authority 12 working days before the poll, ${ }^{32}$ which in 2019 meant 7 May 2019.

\section{MILLION CAMPAIGN \#DENIEDMYVOTE}

On 21 May 2019, two days before the elections, Nicolas Hatton, a chief executive officer of the3million organization, representing the voice and concerns of EU citizens in the UK, submitted a formal complaint to the Electoral Commission concerning the process of EU citizens registering to vote in the 2019 European Parliamentary Election. ${ }^{33}$ It addressed the issue of the formalities required of EU citizens wishing to participate in the elections. Nicolas Hatton recommended allowing EU citizens to sign a statement at the polling station that their vote will only be used in the $U K^{34}$ and described the situation which took place in May 2019 as the disenfranchisement. He referred to the confusion arising from the fact that EU citizens were required to complete an additional form, a step which was not expected of British citizens. The letter suggested that not only the Electoral Commission's conduct has created unnecessary confusion and placed barriers in the way of exercising voting rights for EU27 citizens in the UK, but also - via its lack of clear guidance - has led to an inconsistent approach by local authorities to the

29 There are special arrangements in place granting voting rights to the citizens of the Republic of Ireland.

30 "European Parliament", The Electoral Commission, at <https://www.electoralcommission.org. $\mathrm{uk} / \mathrm{i}$-am-a/voter/types-elections/european-parliament>.

31 "European Union Citizens - European Parliament Voter Registration Form (GB)", The Electoral Commission, at <https://www.electoralcommission.org.uk/sites/default/files/2019-09/EU-citizen-European-Parliament-voter-registration-form-English.pdf $>$.

32 Ibid.

33 N. Hatton, $t 3 m$ Complaint to the Electoral Commission in Advance of the European Elections, 21 May 2019, at <https://docs.wixstatic.com/ugd/0d3854_a5410691f62646978aebeea05157ef2b.pdf>.

Ibid. 
registration process. ${ }^{35}$ Hatton concluded that as a consequence equal access to voting rights has been effectively undermined.

On 28 May 2019 Kieran Rix responded to the formal complaint on behalf of the Electoral Commission. ${ }^{36}$ Referring to Hatton's recommendation on EU citizens signing the statement described above, Rix stated that such a solution was impossible under the current legislation, and any changes to the registration process would require legal actions taken by the UK Government and Parliament. Rix also mentioned a multi-media awareness campaign run by the Electoral Commission from 18 April highlighting the requirement of completing and returning the additional form for EU citizens. The Electoral Commission also contacted Electoral Returning Officers (EROs) advising them to identify local EU citizens. While Rix seemed to be empathizing with the frustration felt by some EU27 citizens, and acknowledged the very short notice of the UK's participation ${ }^{37}$ in the EU elections, he made it clear that he did not consider any of the complaint to be upheld. However, he mentioned that these issues might be again considered while preparing a regular report on the conduct of the elections.

The3million organization decided to take further steps against the UK Government and is currently crowdfunding in order to fulfil that goal..$^{38}$

\section{THE ELECTORAL COMMISSION REPORTS}

On 8 October the Electoral Commission published a report on the May 2019 elections as well as the results of the inquiry into the process of voting registration for EU citizens. ${ }^{39}$ In the Inquiry Report, the Commission acknowledged difficulties experienced by some EU citizens, stating that as a result, some people who were entitled to vote and wanted to vote in the European Parliamentary elections in the UK were unable to do so. ${ }^{40}$ Three main areas of concern have been identified, with EU citizens (1) not being aware

35 Ibid.

36 K. Rix, Electoral Commission Reply to t3m Complaint, 29 May 2019, at <https://docs.wixstatic.com/ ugd/0d3854_c37e17ebac204c949a88a0b4e9420aca.pdf>.

37 Ibid.

38 See N. Hatton, “\#DeniedMyVote Was Unlawful - Help the3million Challenge The Government”, Crowd Justice, at <https://www.crowdjustice.com/case/denied/>.

39 "Inquiry Report: The Voting Registration Process for EU Citizens Resident in the UK for the 2019 European Parliamentary Elections Held in the UK", The Electoral Commission, at <https:// www.electoralcommission.org.uk/who-we-are-and-what-we-do/elections-and-referendums/ past-elections-and-referendums/european-parliamentary-elections/inquiry-report-voting-registration-process-eu-citizens-resident-uk-2019-european-parliamentary>; "Report: May 2019 European Parliamentary Elections and Local Elections", The Electoral Commission, at <https://www.electoralcommission.org.uk/who-we-are-and-what-we-do/elections-and-referendums/past-elections-and-referendums/european-parliamentary-elections/report-may-2019-european-parliamentary-elections-and-local-elections $>$. 
of all the formal requirements (an additional declaration), (2) not being able to fulfil all the necessary steps in time and finally (3) even when thinking they had submitted all the proper documents, not being included on the register and therefore not being able to vote.

The Inquiry Report highlighted the fact that EU citizens had to submit an additional form even if they were already registered to vote for local government elections.$^{41}$ It was also mentioned that while the registering process could be done easily online, the additional form needed to be signed and posted. The report also mentioned the possibility of submitting a scanned copy via e-mail, although no such option was in fact mentioned on the form itself or directly on the website. ${ }^{42}$

The Inquiry Report also emphasised difficulties connected with the long uncertainty about whether these elections would indeed take place in the United Kingdom. For instance, it was mentioned that it was not before 1 April that the UK Government officially confirmed reimbursement for election-related activities. Also, such short notice about the elections significantly reduced any planning time, which certainly affected the public awareness campaign. ${ }^{43}$

The Inquiry Report addressed the work of the Electoral Registration Officers (EROs). They were asked for feedback on their experience in reference to EU citizens. Their input again highlighted difficulties arising from the late notice and the legislation around EU electors. ${ }^{44}$ The representatives of the Electoral Commission also inquired about the number of UC1 forms being sent to those EU citizens who had already been registered to participate in local government elections. The number given is 2.4 million forms, most of them sent for print and dispatch by 18 April 2019.45

The Inquiry Report also provided information about the number of EU citizens who were registered to vote in the 2019 European Parliamentary elections. The numbers provided are strikingly lower, showing only $21 \%$ of citizens who had been

41 Ibid. The last local elections took place on 2 May 2019, in England and Northern Ireland. It is also worth mentioning that the citizens of the Republic of Ireland, Cyprus and Malta are exempt from this requirement.

42 I did my best to analyse and compare the current website of the Electoral Commission, especially the section devoted to the European Parliamentary elections, at <https://www.electoralcommission.org. $\mathrm{uk} / \mathrm{i}$-am-a/voter/types-elections/european-parliament $>$, with the previous one, mentioned in the report, Your Vote Matters website and accessible via Internet Archive Wayback Machine, at <https:// web.archive.org/web/20190411235907/; https://www.yourvotematters.co.uk/how-am-i-represented/european-parliment $>$. When analysing different versions of the latter website, one can notice that the information provided there was being expanded, updated and modified in April 2019. Nowhere did I manage to find the suggestion of contacting the local authorities via e-mail, although it is highly likely that email addresses of the local authorities were provided.

43 "Inquiry Report..."

44 For example, the proper legislation setting the date of polling day was not made before 8 April (came into force on 10 April). See ibid.

45 Ibid. Given that the official notice about the election appeared at the beginning of April, the task undertaken by the EROs was indeed impressive. 
previously included in May 2019 local government register. In other words, approximately 450000 people, only one-fifth of those who had previously been included in the electoral registers, did properly complete all the requirements to vote in the EP elections.

Analysing the reasons behind the EU citizens being unable to vote, the Electoral Commission - as mentioned before - has identified three areas. The first was caused by a lack of awareness of the necessity of an additional declaration. Some electors even upon receiving the $\mathrm{UC} 1$ form did not understand that they needed to complete it, ${ }^{46}$ the report indicated. However, cases were also mentioned in which electors had successfully registered for the previous elections (taking place on 2 May) and wrongly assumed they needed to pursue no further action, especially when the confirmation received did not signal such an obligation. ${ }^{47}$ The second area of concern was linked to the electors who did not manage to submit an additional form in time before the deadline on 7 May 2019, because they found out about this requirement too late or the ERO had not received their submission in time. Finally, there were complaints raised by those EU citizens who had submitted a declaration before the deadline but on 23 May found out they could not vote. Some of those claimed that the ERO did not accept their submission (as it had been done online), had made a clerical error, or wrongly denied receiving the form in time. ${ }^{48}$

Finally, the Inquiry Report mentioned similar issues and concerns identified already at the 2014 European Parliamentary Elections, as also then "a significant number" of EU citizens were unable to vote. Unfortunately, all the work and consideration on needed changes to be introduced into the electoral system came to a halt after the 2016 referendum. ${ }^{49}$

On the same day, 8 October 2019, the Electoral Commission also published their statutory report covering both the 2 May local election in England and in Northern Ireland and the 23 May European Parliament elections. The level of satisfaction measured in national polls was lower than in previous years for both the elections, although the majority of voters still said they were confident that elections were well-run.

The reasons for the lack of confidence varied.

The highest percentage of non-confident respondents within the last five years (not including 12 December General Elections) was recorded for the 2014 EP elections, the 2017 UK Parliamentary General Elections and the 2019 EP Elections. During the 2014 EP Elections the main reasons for not feeling confident were related to a lack of information or understanding; ${ }^{50}$ during the 2017 UK PGE elections again it was a lack

46 Ibid.

${ }^{47}$ It is quite likely that at that time the EU elections were not thought to take place in the UK.

48 "Inquiry report..."

49 Ibid.

50 "The European Parliamentary Elections and the Local Government Elections in England and Northern Ireland. May 2014. Report on the administration of the 22 May 2014 Elections", The Electoral Commission, July 2014, p. 13, at <https://www.electoralcommission.org.uk/sites/default/files/pdf_ file/EP-and-local-elections-report-May-2014.pdf >. 
of information but also distrust towards politicians and the political system, ${ }^{51}$ while during the 2019 EP Elections the most common reason was that some people did not have the opportunity to vote. ${ }^{52}$

Chart 2. Confidence that elections were well-run, 2014-2019. The Electoral Commission..$^{53}$

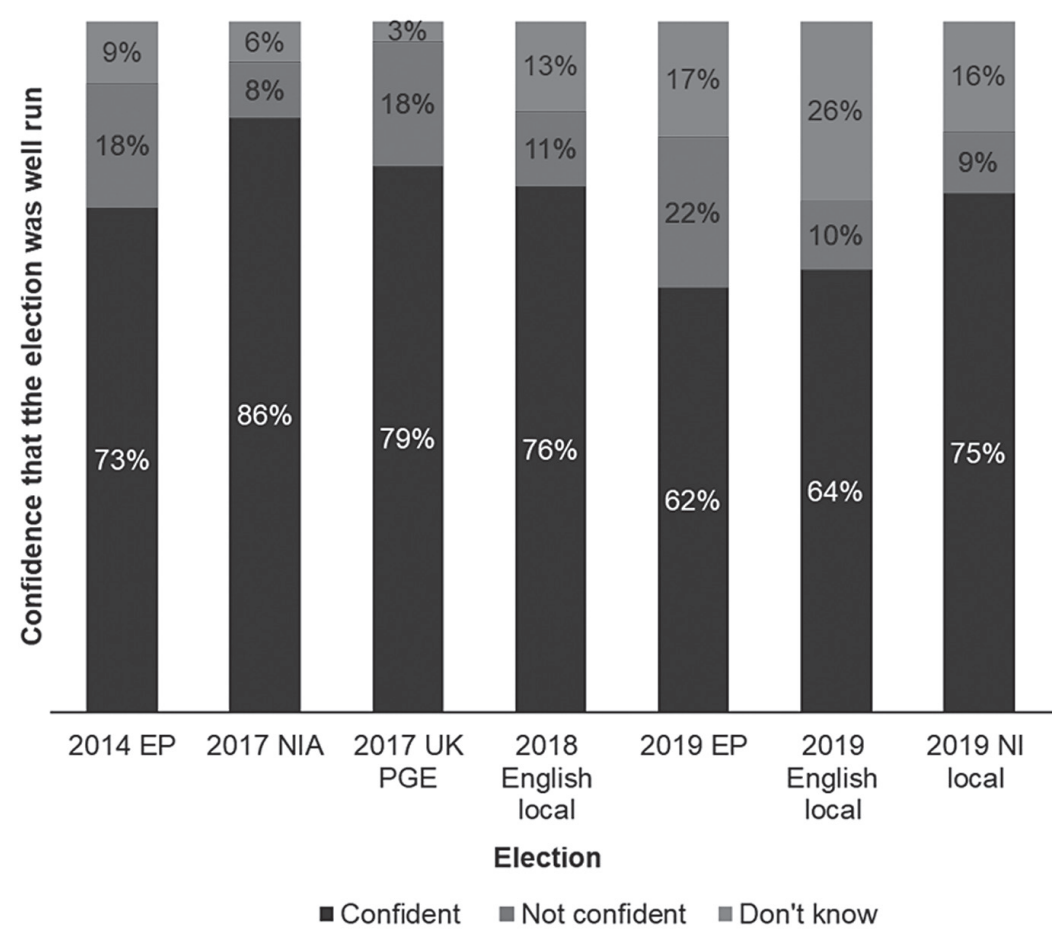

It is clear that the issue received some serious media attention, as many media outlets covered this story. ${ }^{54}$

51 "The Administration of the June 2017 UK General Election. Report on the 8 June 2017 UK Parliamentary General Election", The Electoral Commission, December 2017, p. 4, at <https://www.electoralcommission.org.uk/sites/default/files/pdf_file/The-administration-of-the-June-2017-UK-general-election.pdf>.

52 “Report: May 2019..." See also P. Newbold, L. Piggott, Post-European Elections Poll 2019, 27 June 2019, p. 45, at <https://www.electoralcommission.org.uk/sites/default/files/2019-10/YouGov-\%20 Electoral\%20Commission\%20-\%20Post-EU\%20Elections\%202019_report.pdf>.

53 Report: May 2019 European Parliamentary elections and local elections....

54 See for instance the article on BBC News, A. Therrien, F. Gillett, "EU Citizens in UK Turned away from Polls", BBC News, 23 May 2019, at <https://www.bbc.com/news/uk-politics-48384000> or the story published by the Guardian, E. Graham-Harrison, "'Vote in Your Own Country': EU Citizens Tell of UK Poll Chaos”, The Guardian, 23 May 2019, at <https://www.theguardian.com/politics/2019/may/23/vote-in-your-own-country-eu-citizens-turned-away-from-uk-polls $>$. 


\section{ANALYSING THE NUMBERS}

In the Inquiry Report summarised above, the Electoral Commission openly admitted that it is not possible to conclusively verify how many were affected..$^{55}$ The reason was that there were no comprehensive data sources to determine how many voters wanted to register and were unable to do so, or [...] how many attended a polling station on 23 but were not able to be issued with a ballot paper. ${ }^{56}$

There are some official data available however, which might be used as a reference point. There are estimates of the size of the population of EU citizens in the United Kingdom. According to the newest data released by the Office for National Statistics, there are 3,725,000 EU citizens currently residing in the United Kingdom ${ }^{57}$. The biggest group (46\%) is constituted by the citizens of EU 14 countries, estimated at 1,699,000 people; citizens of EU 8 constitute $38 \%$ of the EU nationals, with 1,427,000 thousand people; and citizens of Bulgaria and Romania (15\%, with 567,000 people); and finally $1 \%$ formed by jointly analysed citizens of Cyprus, Malta and Croatia (32,000 people). It might be worth singling out that this population includes citizens of the Republic of Ireland $(322,000)$, Cyprus $(14,000)$ and Malta, who were exempted from the requirement of providing the $\mathrm{UC} 1$ form. ${ }^{58}$

Out of those people 2,842,000 are above the age of $16 .{ }^{59}$ The minimum age to participate in the EP elections was 18.

We also have access to data on the EU Settlement Scheme, designed to provide EU citizens with UK immigration status after this country leaves the EU. The total number of applications as of 30 November 2019 was 2,592,800. ${ }^{60}$

Against this data, it is possible to look again at the numbers provided by the Electoral Commission. As mentioned above, 2,423,563 UC1 forms were dispatched, which

\footnotetext{
"Inquiry Report..."

Ibid.

57 A. Blake, "Population of the UK by Country of Birth and Nationality", Office for National Statistics, 28 November 2019, sec. Table 2.1, at <https://www.ons.gov.uk/peoplepopulationandcommunity/ populationandmigration/internationalmigration/datasets/populationoftheunitedkingdombycountryofbirthandnationality>.

58 Ibid. Comp. C. Vargas-Silva, M. Fernández-Reino, "EU Migration to and from the UK", Migration Observatory, 30 September 2019, at <https://migrationobservatory.ox.ac.uk/resources/briefings/eumigration-to-and-from-the-uk/>.

59 Certainly these are estimates, based mainly on the Annual Population Survey, which is a household survey, with quite a big sample size of 300000 people. More information on the methodology of this survey can be found at the ONS websites, see "Population by Country of Birth and Nationality QMI", Office for National Statistics, at <https://www.ons.gov.uk/peoplepopulationandcommunity/populationandmigration/internationalmigration/methodologies/populationbycountryofbirthandnationalityqmi>.

60 "EU Settlement Scheme Statistics, November 2019. Experimental Statistics", Home Office, 17 December 2019, p. 7, at <https://assets.publishing.service.gov.uk/government/uploads/system/uploads/attachment_data/file/852619/eu-settlement-scheme-statistics-november-2019.pdf>.
} 
roughly mirrors the estimated adult population of $\mathrm{EU}$ citizens minus the citizens of Ireland, Cyprus and Malta. Around 450,000 UC1 forms were properly processed. Approximately $80 \%$ of the registered EU citizens $(1.7$ million) did not fulfil all the requirements to participate in the EU elections.

It is not possible to estimate how many EU citizens chose to participate in the EP elections in their country of origin.

However, it might be useful to look at the available data on the Polish citizens currently residing in the United Kingdom. There are estimates of 902,000 Polish citizens, ${ }^{61}$ and 483,800 applications from Polish citizens were received within the EU Settlement Scheme ${ }^{62}$. During the last parliamentary national elections, there were 99,503 Polish citizens residing in the UK who had registered to participate in these elections, ${ }^{63}$ but only 21,773 persons registered to participate in the EP elections via the Polish diplomatic institutions. ${ }^{64}$ Again, it is difficult to interpret these numbers as they might reflect lower interest in EP elections, or on the contrary, willingness to participate in the European Parliamentary elections via their country of residence, the United Kingdom. ${ }^{65}$

\section{CONCLUSIONS}

The3million organization is currently campaigning to extend electoral rights to all residents in the United Kingdom and all British citizens living outside the UK, ${ }^{66}$ meaning all the British residents could participate in all the general elections and referendums. They support their demands by pointing out that the United Kingdom is now experiencing a time of radical change and constitutional shifts, ${ }^{67}$ where the meanings of citizenship, democracy and governance are being debated. It is undeniable that since the Brexit referendum (2016) EU citizens residing in the UK have entered a phase of anxiety and uncertainty. While the ruling Conservative Party might not be inclined to listen to the voices

61 A. Blake, "Population of the UK..."

62 "EU Settlement Scheme Statistics..."

63 "Frekwencja w wyborach 2019 r. do Sejmu. Wielka Brytania", Państwowa Komisja Wyborcza, at <https://wybory.gov.pl/sejmsenat2019/pl/frekwencja/Koniec/sejm/gm/826>.

64 "Frekwencja w wyborach 2019 r. do Parlamentu Europejskiego. Gmina zagranica", Państwowa Komisja Wyborcza, at <https://pe2019.pkw.gov.pl/pe2019/pl/frekwencja/Koniec/gm/149901>.

65 There is some research done for the European Commission on electoral rights suggesting that EU citizens do not have "strong preference for or against voting in the EP elections in their country of residence or in their country of origin". See "Flash Eurobarometer 431. Summary. Electoral Rights", European Commission, March 2016, at <https://ec.europa.eu/info/sites/info/files/2016-summary-flash-eurobarometer-431-electoral-rights_en.pdf >.

66 Currently, British citizens leave their voting rights after 15 years of living abroad. See "Briefing for Panellists - Launch of 'Let us Vote' Campaign, 8 May 2019", 3million organisation, at <https://static. wixstatic.com/ugd/0d3854_1af1f4029ae24c98ae9a32ea0a6d8135.pdf>. Cf. E.-M. Poptcheva, Disenfranchisement of EU Citizens Resident Abroad. Situation in National and European Elections in EU Member States, European Parliamentary Research Service, 18 August 2015.

67 "Briefing for Panellists..." 
of this particular community, ${ }^{68}$ it does not change the fact that the deeply divided society would benefit from more trust and inclusion. The question of how EU citizens will be able to politically participate and influence the public policies in the post-Brexit era requires not only a clear political vision but also high-quality institutional arrangements.

\section{BIBLIOGRAPHY}

"The Administration of the June 2017 UK General Election. Report on the 8 June 2017 UK Parliamentary General Election", The Electoral Commission, December 2017, at <https:// www.electoralcommission.org.uk/sites/default/files/pdf_file/The-administration-of-theJune-2017-UK-general-election.pdf>, 5 December 2019.

Aylott N., "Britain: Political Parties Polarising", in N. Bolin et al. (eds.), Euroflections. Leading Academics on the European Elections 2019, Sundsvall 2019, at <https://www.euroflections. se/globalassets/ovrigt/euroflections/euroflections_v3.pdf>.

Blake A., "Population of the UK by Country of Birth and Nationality", Office for National Statistics, 28 November 2019, at <https://www.ons.gov.uk/peoplepopulationandcommunity/ populationandmigration/internationalmigration/datasets/populationoftheunitedkingdombycountryofbirthandnationality $>, 5$ December 2019.

"Briefing for Panellists - Launch of 'Let us Vote' Campaign, 8 May 2019", 3million organisation, at https://static.wixstatic.com/ugd/0d3854_1af1f4029ae24c98ae9a32ea0a6d8135. pdf, 7 November 2019.

Buchan L., "Boris Johnson Urged to Apologise for 'Scapegoating Migrants' on Eve of General Election”, The Independent, 11 December 2019, at https://www.independent.co.uk/ news/uk/politics/boris-johnson-general-election-migrants-apology-eu-citizens-brexit-a9242121.html, 18 December 2019.

Carter E., Loomes G., Lundberg T.C., "United Kingdom” in W. Gagatek (ed.), The 2009 Elections to the European Parliament: Country Reports, Florence 2010.

"EU Settlement Scheme Statistics, November 2019. Experimental Statistics", Home Office, 17 December 2019, at <https://assets.publishing.service.gov.uk/government/uploads/ system/uploads/attachment_data/file/852619/eu-settlement-scheme-statistics-november-2019.pdf>, 18 December 2019.

"European Election 2019: The UK's Results in Maps and Charts", BBC News, 27 May 2019, at https://www.bbc.com/news/uk-politics-48403131, 5 December 2019.

"European Parliament", The Electoral Commission, at <https://www.electoralcommission.org. uk/i-am-a/voter/types-elections/european-parliament $>$.

"The European Parliamentary Elections and the Local Government Elections in England and Northern Ireland. May 2014. Report on the administration of the 22 May 2014 Elections", The Electoral Commission, July 2014, at <https://www.electoralcommission.org.uk/sites/ default/files/pdf_file/EP-and-local-elections-report-May-2014.pdf>, 15 November 2019.

68 See for instance, L. Buchan, "Boris Johnson Urged to Apologise for 'Scapegoating Migrants' on Eve of General Election”, The Independent, 11 December 2019, at <https://www.independent.co.uk/news/ uk/politics/boris-johnson-general-election-migrants-apology-eu-citizens-brexit-a $9242121 . h t m l>$. 
"European Union Citizens - European Parliament Voter Registration Form (GB)", The Electoral Commission, at https://www.electoralcommission.org.uk/sites/default/files/2019-09/ EU-citizen-European-Parliament-voter-registration-form-English.pdf, 5 December 2019.

"Flash Eurobarometer 431. Summary. Electoral Rights", European Commission, March 2016, at https://ec.europa.eu/info/sites/info/files/2016-summary-flash-eurobarometer-431-electoral-rights_en.pdf, 5 December 2019.

"Frekwencja w wyborach 2019 r. do Parlamentu Europejskiego. Gmina zagranica”, Państwowa Komisja Wyborcza, at https://pe2019.pkw.gov.pl/pe2019/pl/frekwencja/Koniec/gm/149901, 15 December 2019.

"Frekwencja w wyborach 2019 r. do Sejmu. Wielka Brytania", Państwowa Komisja Wyborcza, at https://wybory.gov.pl/sejmsenat2019/pl/frekwencja/Koniec/sejm/gm/826, 15 December 2019.

Graham-Harrison E., “Vote in Your Own Country': EU Citizens Tell of UK Poll Chaos”, The Guardian, 23 May 2019, at https://www.theguardian.com/politics/2019/may/23/vote-inyour-own-country-eu-citizens-turned-away-from-uk-polls, 2 December 2019.

Hatton N., “\#DeniedMyVote Was Unlawful - Help the3million Challenge The Government”, Crowd Justice, at https://www.crowdjustice.com/case/denied/, 5 December 2019.

Hatton N., t3m Complaint to the Electoral Commission in Advance of the European Elections, 21 May 2019, at https://docs.wixstatic.com/ugd/0d3854_a5410691f62646978aebeea 05157ef2b.pdf, 5 December 2019.

"Inquiry Report: The Voting Registration Process for EU Citizens Resident in the UK for the 2019 European Parliamentary Elections Held in the UK", The Electoral Commission, at https://www.electoralcommission.org.uk/who-we-are-and-what-we-do/elections-and-referendums/past-elections-and-referendums/european-parliamentary-elections/inquiry-report-voting-registration-process-eu-citizens-resident-uk-2019-european-parliamentary, 15 December 2019.

Kubin T., "Wyjście Wielkiej Brytanii z Unii Europejskiej a zróżnicowanie integracji w UE”, Studia Europejskie, vol. 1 (2018).

Lilleker D., "Voter Psychology in the Age of Anger: UK 2019", in N. Bolin et al. (eds.), Euroflections. Leading Academics on the European Elections 2019, Sundsvall 2019, at https://www. euroflections.se/globalassets/ovrigt/euroflections/euroflections_v3.pdf, 5 December 2019.

Newbold P., Piggott L., Post-European Elections Poll 2019, 27 June 2019, at <https://www.electoralcommission.org.uk/sites/default/files/2019-10/YouGov-\%20Electoral\%20Commission\%20-\%20Post-EU\%20Elections\%202019_report.pdf>, 5 November 2019.

Poptcheva E.-M., Disenfranchisement of EU Citizens Resident Abroad. Situation in National and European Elections in EU Member States, European Parliamentary Research Service, $18 \mathrm{Au}$ gust 2015, https://doi.org/10.2861/115885.

"Population by Country of Birth and Nationality QMI", Office for National Statistics, at https://www.ons.gov.uk/peoplepopulationandcommunity/populationandmigration/internationalmigration/methodologies/populationbycountryofbirthandnationalityqmi, 5 December 2019.

"Report: May 2019 European Parliamentary Elections and Local Elections", The Electoral Commission, at https://www.electoralcommission.org.uk/who-we-are-and-what-we-do/elections- 
and-referendums/past-elections-and-referendums/european-parliamentary-elections/report-may-2019-european-parliamentary-elections-and-local-elections, 5 December 2019. Rix K., Electoral Commission Reply to t3m Complaint, 29 May 2019, at https://docs.wixstatic. com/ugd/0d3854_c37e17ebac204c949a88a0b4e9420aca.pdf, 5 December 2019.

Ruszkowski J., Parlament Europejski. Dynamika instytucjonalna i kompetencyjna, Szczecin 2010. Smets K., "United Kingdom: European Elections in the Run-Up to Brexit", in L. De Sio, M.N. Franklin, L. Russo (eds.), The European Parliament Elections of 2019, Roma 2019.

"Statement by the European Council (Art. 50) on the UK notification", European Council, 29 March 2017, at http://www.consilium.europa.eu/en/press/press-releases/2017/03/29/euco-50-statement-uk-notification/, 15 November 2019.

Therrien A., Gillett F., "EU Citizens in UK Turned away from Polls", BBC News, 23 May 2019, at https://www.bbc.com/news/uk-politics-48384000, 5 December 2019.

Tilindyte L., "EU Citizenship Rights. Briefing", European Parliamentary Research Service, March 2017, at <https://www.europarl.europa.eu/RegData/etudes/BRIE/2017/599361/ EPRS_BRI(2017)599361_EN.pdf>, 5 December 2019.

Vargas-Silva C., Fernández-Reino M., "EU Migration to and from the UK", Migration Observatory, 30 September 2019, at https://migrationobservatory.ox.ac.uk/resources/briefings/ eu-migration-to-and-from-the-uk/, 5 December 2019.

Webb P., "United Kingdom 2019 - the Election that Wasn't Supposed to Be", in N. Bolin et al. (eds.), Euroflections. Leading Academics on the European Elections 2019, Sundsvall 2019, at https://www.euroflections.se/globalassets/ovrigt/euroflections/euroflections_v3.pdf>, 5 December 2019.

Węc J.J., "Pozycja Parlamentu Europejskiego w reżimie traktatu lizbońskiego", in A. Kirpsza, P. Musiałek, D. Stolicki (eds.), Podsumowanie siódmej kadencji Parlamentu Europejskiego (2009-2014), Kraków 2015.

Wierzchowska A., "Parlament Europejski: efektywny katalizator zmian ustrojowych czy niedecyzyjny współuczestnik? Ocena pozycji Parlamentu Europejskiego w systemie politycznym Unii Europejskiej z uwzględnieniem kadencji 2014-2019”, in A. Nitszke, J.J. Węc (eds.), Podsumowanie VIII kadencji Parlamentu Europejskiego. Wyzwania integracji europejskiej w latach 2014-2019, Kraków 2019.

Zuba K., Dryfujące wyspy. Europejskie dylematy Brytyjczyków, Warszawa 2013.

Matgorzata KUŁAKOWSKA - PhD, an assistant professor at the Institute of Political Science and International Relations of the Jagiellonian University. She holds an MA in both political science and sociology. An author of more than a dozen articles devoted to British politics and society, multiculturalism and migration, and a monograph on community cohesion project in the United Kingdom (Searching for community cohesion. British policies 2001-2010); also a co-editor of three books (Studies on multiculturalism, 2010; Facets of election campaigns in 2015, 2016 - both in Polish, and Political Science in Europe at the beginning of the $21^{\text {st }}$ Century, 2015) and an editorial assistant of the academic journal "Teoria Polityki". 